\section{ELEMENTOS HISTOLÓGICOS CARACTERÍSTICOS DE CECROPIA PACHYSTACHYA TRÉCUL (EMBAÚBA)}

Luzia llza Ferreira Jorge * Blanca Elena Ortega Markman * Vicente de Oliveira Ferro **

São descritas as características anatômicas da folha, do pecíolo e das cascas caulinares da espécie Cecropia pachystachya Trécul com o objetivo de identificar o vegetal fragmentado, empregado medicinalmente. Anexos epidérmicos e inclusões celulares permitem a diagnose a partir das folhas. Peculiaridades das fibras, dos esclereídeos e dos vasos permitem o reconhecimento através das cascas.

Unitermos: Cecropia pachystachya Trécul, embaúba, umbaúba.

\section{INTRODUÇÃO}

Cecropia pachystachya Trécul (embaúva, embaúba, umbaúba, ambaíba, árvore-da-preguiça) ${ }^{2}$ é árvore de 4-7 $\mathrm{m}$ de altura, com tronco de $15-25 \mathrm{~cm}$ de diâmetro, nativa em nosso país. As folhas são muito apreciadas pelo bicho-preguiça e os frutos pelos pássaros. É também útil nos reflorestamentos devido à rapidez do seu crescimento ${ }^{2}$.

A espécie não contém alcalóides ${ }^{1,5}$, mas apresenta expressiva concentração de esteróides e de substâncias flavonicas nas folhas e

* Bromatologia e Química - Instituto Adolfo Lutz

** Departamento de Farmácia, Faculdade de Ciências Farmacêuticas - USP no caule, sendo empregada em substituiçăo à digitalis como tônico cardíaco ${ }^{1,4}$. É também excelente diurético ${ }^{1,5}$.

O objetivo deste trabalho é fornecer subsídios à identificação microscópica da espécie a partir das folhas e das cascas, que são as partes empregadas na medicina e nas rações animais. Os "ABSTRACTS" năo registram estudos anatômicos da espécie.

\section{MATERIAL E MÉTODOS}

Foram coletadas amostras de folhas e de cascas de um exemplar de Cecropia pachystachya Trécul existente no pomar do Instituto de Biociências da USP, São Paulo, SP, para estudo histológico. A pesquisadora Lúcia Rossi do Instituto de Botânica, nesta Capital, identificou a espécie por confrontação com exsicatas e com a literatura especializada em taxonomia.

O estudo anatômico foi procedido através de cortes a mão livre submetidos a reaçăo de descoloração com solução de hipoclorito de sódio a $10 \%$ e reações de coloração com solução de lugol e floroglucina clorídrica (solução saturada a 20\%).

\section{RESULTADOS}

\section{Características morfológicas e anatômicas}

As folhas têm cerca de $30 \mathrm{~cm}$ de diâmetro, são peltadas e têm os bordos partidos em 8-10 lobos. A epiderme superior é um tanto áspera e a inferior é níveo-tomentosa.

As dimensōes periclinais e anticlinais das células da epiderme superior são relativamente maiores que as das células da epiderme inferior (Figuras 1-A, 1-B, 1-C e 1-D). As células epidérmicas têm contorno poligonal quando observadas de face, e alongado periclinal ou anticlinalmente quando observadas radialmente (Figuras 1-A, 1-B, 1-C e 1-D). Os estômatos, na epiderme inferior, são do tipo anomocítico (Figura 1-B) e apresentam-se um pouco acima do nível da demais células epidérmicas (Figura 1-D). Compensatóriamente, porém, săo revestidos por abundantes tricomas filariformes, contorcidos, de paredes paralelas, que conferem um aspecto esbranquiçado ao olho nú e aveludado ao tato para a epiderme inferior da folha (Figura 1-D). Algumas células da epiderme superior apresentam-se horizontalmente divididas (Figura 1-C) quando observadas em corte transversal. 
O mesofilo tem simetria dorsiventral, com uma camada de células constituindo o parênquima paliçádico, que é sucedido por várias camadas de parênquima lacunoso. Os feixes vasculares são circundados por bainhas de feixe conectadas à epiderme superior através de extensōes dessas bainhas (Figura 1-C).

A vascularizaçâo é do tipo colateral aberta. Há drusas isoladas contidas em idioblastos do parênquima paliçádico e lacunoso próximos aos feixes vasculares (Figura 1-C). Tricomas tectores unicelulares, ponteagudos, de base larga e tricomas glandulares pluricelulares (pedicelo com 2 células e cabeça com seis ou mais células) são observados na epiderme superior (Figura 1-C). Em folhas velhas ocorre ablação dos pêlos filariformes encontrados na epiderme inferior, descritos anteriormente (Figura 1-D).

A nervura central observada em corte transversal, apresenta feixes colaterais abertos individualmente ou ligeiramente anastomosados pelo crescimento secundário, dispostos em circunferência que delimita uma região cortical e uma regiáo medular, esta última relativamente bem desenvolvida. O diâmetro das células medulares é maior que o das células corticais, estrutura que se repete no peciolo. Drusas fazem-se presentes também nesta regiáo, sempre relacionadas aos vasos. As células epidérmicas são radialmente alongadas (corte transversal) e miúdas se comparadas às células parenquimáticas. Há tricomas tectores de base larga e tricomas glandulares pluricelulares idênticos aos descritos para 0 limbo foliar. Há colênquina bem desenvolvido de ambos os lados.

\section{Pecíolo}

A estrutura anatômica do pecíolo é semelhante à da nervura central, porém, mais desenvolvida: o sistema vascular tem abundante estrutura secundária e delimita uma região cortical e uma região medular. O parênquima cortical é escasso se comparado ao medular, apresentando-se comprimido pelo crescimento secundário do sistema vascular de um lado e pelo crescimento do colênquima de outro. As células epidérmicas são pequenas e radialmente alongadas quando observadas no corte transversal. Abaixo dessa epiderme ocorrem várias camadas de colênquima do tipo angular, que é bastante desenvolvido, constituído de várias camadas celulares. Há drusas isoladas, contidas em idioblastos do colênquima e do parênquima cortical. Tricomas tectores de base larga e tricomas glandulares idênticos aos tricomas foliares são observados também no pecíolo.

Caule

O caule apresenta diversos elementos histológicos característicos: células parenquimáticas ovóides de paredes delgadas (Figura 1 E), fibras de terminações arrendondadas, diferentes das fibras com terminação em bisel que ocorrem vulgarmente nos mais diversos vegetais (Figura 1-F), idioblastos contendo drusas. (Figura 1-E), células de súber, vasos espiralados calibrosos, de diâmetro dilatado e vasos pontoados estreitos, bem como esclereídeos fibriformes, de paredes grossas e tortuosas (Figura 1-F).

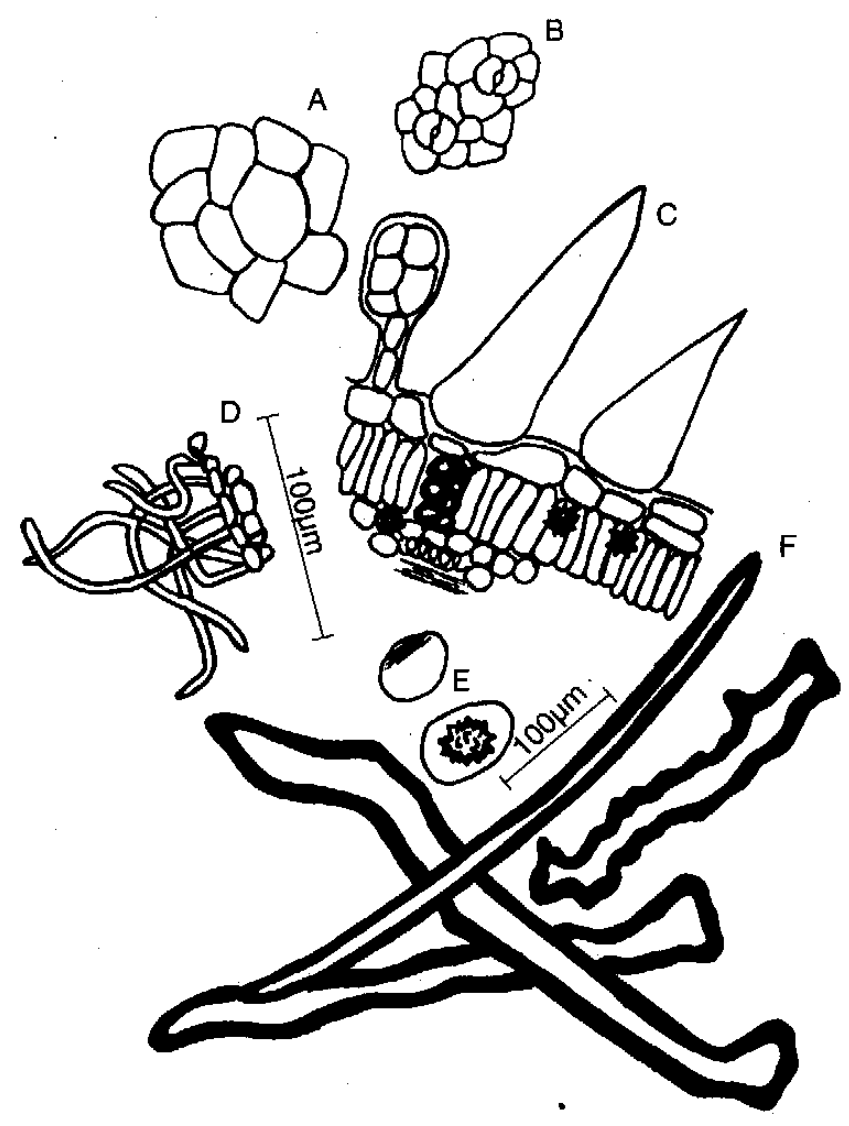




\section{DISCUSSÃO}

A espécie em estudo obedece ao padrão anatômico da família a que pertence (Moraceae) ${ }^{3}$ sob diversos aspectos: dorsiventralidade foliar, estômatos localizados na epiderme inferior, células epidérmicas foliares horizontalmente divididas, drusas e tricomas. Contudo, a ausência de canais secretores e de cistólitos parece-nos uma peculiaridade dessa morácea, uma vez que METCALFE \& $\mathrm{CHALK}^{3}$ afirma a universalidade dessas características dentro da família. Não observamos inclusóes de sílica nos tricomas de Cecropia pachystachya Trecul ${ }^{3}$.

\section{CONCLUSÖES}

Elementos histológicos característicos das folhas são: tricomas de base larga e ápice ponteagudo, tricomas glandulares pluricelulares, tricomas fibriformes (epiderme inferior de folhas jovens), drusas e estômatos anomocíticos.

Elementos histológicos característicos do caule sáo: fibras de terminaçōes abauladas, drusas, células de súber, vasos espiralados lagos, vasos pontuados estreitos e fibro-esclereídeos tortuosos.

AGRADECIMENTO: Agradecemos à Dra. Lúcia Rossi, referida em MATERIAL E MÉTODOS, pela identificação da espécie Cecropia pachystachya Trécul.

\section{ABSTRACT}

Anatomical characteristics of the leaf and the barks of the stem of the species Cecropia pachystachya Trécul are described aiming to identify this species when it is employed for therapeutic purposes. Epidermal annexs and cellular inclusions allow the diagnosis of the species from its leaves. Peculiarities of the fibers, petrea cells and vases allow the recognizing of the barks of the stem of Cecropia pachystachya Trécul.

KEYWORDS: Cecropia pachystachya Trécul, embaúba, umbaúba

\section{REFERÊNCIAS BIBLIOGRÁFICAS}

1. FONSECA, E.T. - Umbaúba ("imbaúba”, Cecropia peltata). Rev. Flora Med., 1:289-96, 1995.

2. LORENZI, H. - Árvores Brasileiras. São Paulo, Plantarum Ltda, 1992, p. 81.

3. METCALFE, C.R.; CHALK, L. - Anatomy of the Dicotyledons. Oxford, Clarendon Press, 1950, v. 2, p. 1259-71.

4. PRISTA, L.N.; ALVES, A.C. - Phytochemical investigation of the bark of Cecropia peltata. Garcia Orta, 8(3):615-28, 1960.

5. VALERI, H.; NARVAES, P.R. - Investigation of Cecropia peltata. Rev. Med. Vet. Parasitol., Caracas, 9:105-16, 1950 (pub. 1951). 